\title{
Geochemical and palaeocurrent analysis of the Tertiary Kerri-Kerri Formation in the Gongola Sub-Basin of the Northern Benue Trough North-eastern Nigeria: implications for provenance, tectonic setting and palaeoweathering
}

\author{
Usman Abubakar ${ }^{1}$ (D) Musa Bappah Usman ${ }^{1} \cdot$ Abdulwahab Mohammed Bello $^{1} \cdot$ Tahir Ahmad Garba $^{1} \cdot$ Sadiq Hassan $^{1}$
}

(c) Springer Nature Switzerland AG 2019

\begin{abstract}
Geochemical and palaeocurrent analysis was carried out on the sediments of the Kerri-Kerri Formation in the Gongola Sub-Basin of the Northern Benue Trough, North-eastern Nigeria in order to infer their provenance, tectonic setting and palaeoweathering conditions in the source area. The sediments of the Kerri-Kerri Formation were geochemically classified as litharenite and greywackes. Provenance studies suggested derivation from pre-existing sedimentary rocks with little influence from felsic igneous rocks, while the tectonic discrimination parameters suggest continental rift of passive margin setting. The weathering indices such as chemical index of alteration, plagioclase index of alteration and chemical index of weathering indicate low to moderate intensity of chemical weathering in the source area. Index of compositional variation and $\mathrm{SiO}_{2} / \mathrm{Al}_{2} \mathrm{O}_{3}$ indicate that the studied sediments are compositionally mature to immature. The palaeocurrent analysis of the Kerri-Kerri Formation suggested south western direction, which indicate that the sediment were source from the north eastern direction. From the provenance studies, source area weathering, and palaeocurrent direction of the Kerri-Kerri Formation, it can be inferred that most of the sediments are from pre-existing Cretaceous sedimentary rocks of the Gongola Sub-Basin and have not undergone long transportation.
\end{abstract}

Keywords Kerri-Kerri Formation · Northern Benue Trough · Provenance · Tectonic Setting · Palaeoweathering and palaeocurrent analysis

\section{Introduction}

Important information about the provenance, palaeoweathering, and tectonic setting of sedimentary rocks can be obtained from their geochemical and mineralogical compositions [1-3]. The techniques used in such studies include petrography, mineral chemistry and geochemical analysis among others [1-6]. In the last few decades, Bhatia [7], Bhatia [8], Bhatia and Crook [9], Roser and Korsch [10] showed the importance of geochemical data as a tool in determining the provenance, palaeoweathering, and tectonic settings of the basin of deposition of ancient terrigenous deposits. Subsequently, several researches have been carried out by various workers on the use of inorganic geochemical data (major-, trace and rare earth elements) as tool in the determination of provenance, tectonic settings of basin of deposition and palaeoweathering conditions $[5,11,12]$.

The Tertiary Kerri-Kerri Formation is the topmost lithostratigraphic unit in the Gongola Sub-Basin of the Northern Benue Trough [13] (Figs. 1, 2). The formation is the only record of Tertiary sedimentation in the Gongola Sub-Basin and it is characterize by whitish grey sandstones, siltstones and claystones with the claystones dominating

Usman Abubakar, uabubakar2002@gmail.com|'Department of Geology, Gombe State University, P.M.B 127, Tudun Wada, Gombe, Gombe State, Nigeria. 


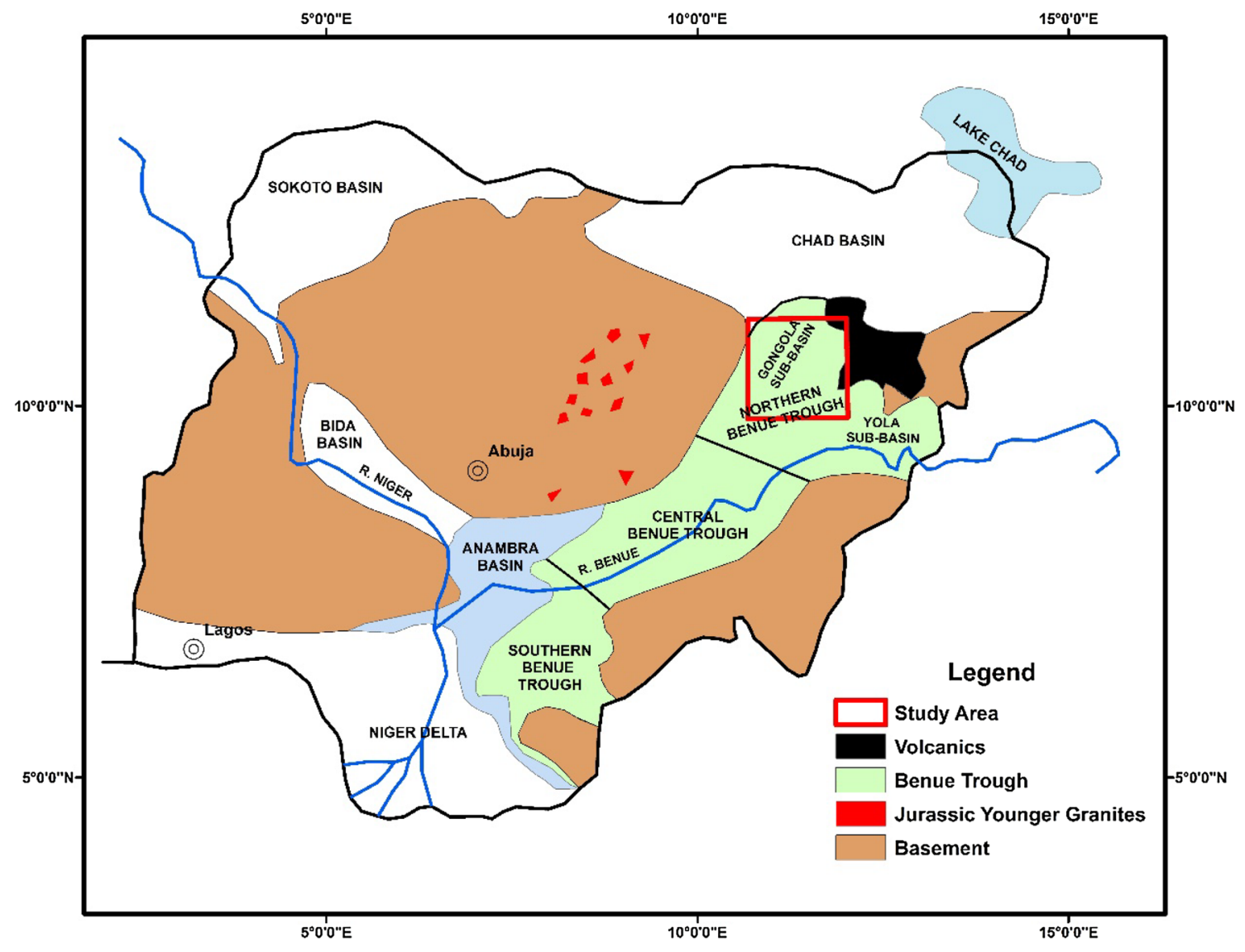

Fig. 1 The Nigerian Benue Trough and study area (after Abubakar [19])

the lithology in most places [14]. The formation is well exposed in Gombe Abba, Dukku, Akko and Alkaleri [15]. Adegoke et al. [15] suggested fluvial, deltaic and marginal lacustrine environment of deposition for Kerri-Kerri Formation from the association of facies and sedimentary structures. Dike [14] considered the Kerri-Kerri Formation as exclusively continental in origin and interpreted the coarsening upward cyclothems of the Formation as alluvial succession.

Most of the studies that have been carried out on the Kerri-Kerri Formation focused on the stratigraphy, sedimentology, palaeoenvironmental interpretation, palaeontological and structural studies [14-17]. However, studies focusing on provenance, tectonic setting and palaeoweathering of the sediments of the Kerri-Kerri Formation are very limited. In this regard, this paper discusses the geochemistry of the Kerri-Kerri Formation of the Gongola Sub-Basin of the Northern Benue Trough. Palaeocurrent analysis is also performed on the primary sedimentary structures of the Formation. The aim of the paper is to investigate the provenance, tectonic setting, chemical weathering condition and palaeocurrent trend of the depositional medium of the Kerri-Kerri Formation.

\section{Geological setting and stratigraphy}

The Benue Trough (Fig. 1) is regarded as rift basin in central West Africa that extends NNE-SSW for over $1000 \mathrm{~km}$ in length and $150 \mathrm{~km}$ in width. The Benue Trough is bounded to the North and South by Chad and Niger Delta basins, respectively $[13,18,19]$. Cretaceous sediments with some Tertiary sediments filled in the Benue Trough (Fig. 2) and attained a total thickness of about $6000 \mathrm{~m}[16,19,20]$. The sediments were associated with some Tertiary volcanics [20]. It is widely believed that the Benue Trough was formed during the breakup of Gondwanaland in the early Cretaceous that led to the separation of Africa and South American plate [18]. King [21] and Stoneley [22] proposed a rift system model associated with tensional movement and host and graben model, respectively, for the evolution of the Benue Trough. Grant [23] proposed a Rift Rift Failed (RRF) triple junction model that led to plate dilation and the opening of the Gulf of Guinea. Aulocogen model was proposed by Olade [24] whereas a wrench faulting was considered by Benkhelil $[18,25]$ and Guiraud and Maurin 
Fig. 2 Stratigraphic successions of Upper Benue Trough (modified after Tukur et al. [28])

\begin{tabular}{|c|c|c|c|c|}
\hline Age & Gongola Arm & Yola Arm & \multicolumn{2}{|c|}{ Paleoenvironment } \\
\hline Tertiary & $\begin{array}{l}\text { Kerri - Kerri } \\
\text { Formation } \\
\text { Gombe } \\
\text { Sandstone }\end{array}$ & Erosion? & \multicolumn{2}{|c|}{$\begin{array}{c}\text { Continental } \\
\text { (Fluvial / Lacustrine) } \\
\text { Continental } \\
\text { (Lacustrine / Deltaic) }\end{array}$} \\
\hline Santonian & \multirow{3}{*}{$\begin{array}{l}\text { Fika Shale } \\
\text { Deban Fulani } \\
\text { Gulani } \\
\text { Dumbulwa } \\
\text { Kanawa }\end{array}$} & \multirow{3}{*}{$\begin{array}{l}\text { Lamja } \\
\text { Numanha } \\
\text { Sekuliye } \\
\text { Jessu } \\
\text { Dukkul }\end{array}$} & \multirow{3}{*}{\multicolumn{2}{|c|}{$\begin{array}{c}\text { Marine } \\
\text { (Offshore / Estuarine) }\end{array}$}} \\
\hline Coniacian & & & & \\
\hline Turonian & & & & \\
\hline Cenomanian & \multicolumn{2}{|c|}{ Yolde Formation } & \multicolumn{2}{|c|}{ Transitional } \\
\hline & \multicolumn{2}{|c|}{ Upper Bima Sandstone Member } & Braided & \\
\hline $\begin{array}{l}\text { older } \\
\text { Precambrian }\end{array}$ & \multicolumn{2}{|c|}{ Lower Bima Sandstone Member } & $\begin{array}{l}\text { Alluvial/Braided } \\
\text { Lacustrine }\end{array}$ & Continental \\
\hline
\end{tabular}

$\ldots \ldots$ Unconformity
[26] as the prevailing tectonic process during the evolution of the Benue Trough.

The Benue Trough is subdivided (Fig. 1) into Northern, Central and Southern portions [13]. The study area is situated in the Northern Benue Trough. The Northern Benue Trough is the North-eastern end of the Benue Trough and it is divided into the $\mathrm{N}-\mathrm{S}$ trending Gongola Sub-Basin and the E-W trending Yola Sub-Basin [13, 27]. In the Gongola Sub-basin, the oldest lithostratigraphic unit (Fig. 2) is the Aptian-Albian thick continental Bima Sandstone that unconformably overlies the Precambrian crystalline basement rocks. The Bima Sandstone is overlain by the transitional Yolde Formation, marine Pindiga Formation and deltaic Gombe Formation [13, 16, 20, 28]. Gombe Formation marked the end of the Cretaceous sedimentation in the Gongola Sub-Basin [20]. The Tertiary Kerri-Kerri Formation overstep the Maastrichtian Gombe Formation unconformably and composed of flat-lying to gently dipping basal conglomerate, grit, sandstone, siltstone and clay [13-15]. Typical sections of the Kerri-Kerri Formation are well exposed in Gombe Abba, Dukku, Akko town and Alkaleri [15]. Two localities (Akko town and Gombe Abba) within the Kerri-Kerri Formation (Fig. 3) were selected for this study. Locality one (Figs. 3, 4a) covers an area around Gombe Abba, which is approximately $90 \mathrm{~km} \mathrm{NW}$ of Gombe town along Gombe to Darazo major road. Locality two (Figs. 3, 4b) (Akko town) is accessible by a major road
(Gombe-Bauchi road) linking Gombe and Bauchi state. There are foot paths linking smaller dispersed communities and a prominent Dam (Akko Dam) that can be clearly noticed within this locality.

\section{Materials and methods}

Fifteen (15) sandstones and Fifteen (15) clays samples were collected from outcrop sections of the Kerri-Kerri Formation around Akko and Gombe Abba areas. The details of sample locations are presented in Fig. 4. Major oxide compositions of the sandstone and clay samples were determine using X-ray fluorescence spectrometer (XRF). For a step by step information about the sample preparation and analytical procedures check Rollinson [29]. The geochemical analysis was carried out at the geochemical laboratory of Ashaka Cement Plc.

A total of 90 palaeocurrent measurements were made on the primary sedimentary structures of the Kerri-Kerri Formation using a Brunton compass clinometer. The measurements were taken from three streams within the study area. The measured primary sedimentary structures include planar cross bedding and trough cross bedding. Tilt correction was not made on the measured palaeocurrent data because the structural dip of the beds of the Kerri-Kerri Formation are generally near horizontal 
Fig. 3 Geological map showing the area underlain by Kerri-Kerri Formation and the studied locations (enlarge in Fig. 4) (modified after Dike [14])

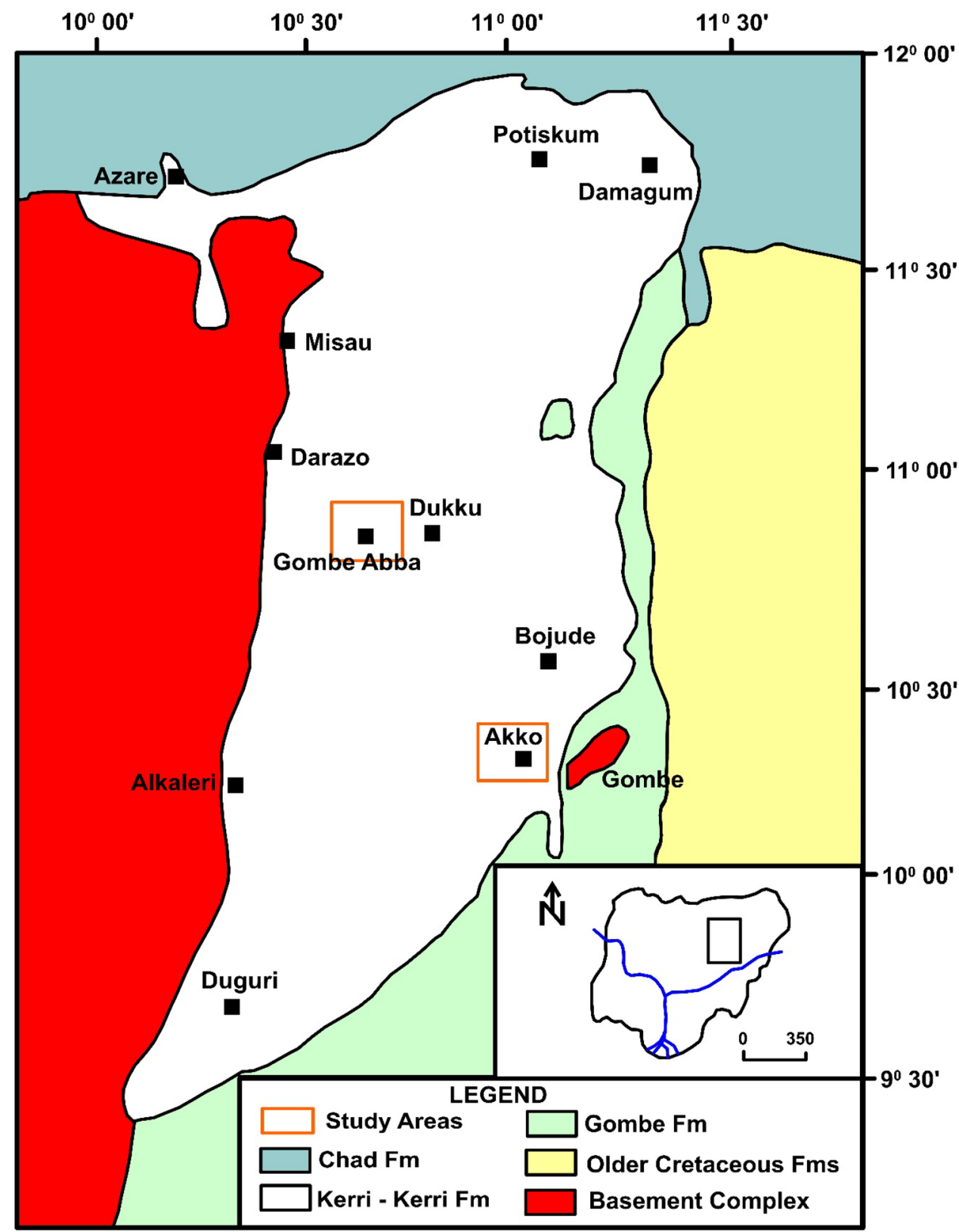

and unaffected by any tectonic activities with dip not exceeding $5^{\circ}$. According to Potter and Pettijohn [30] and Lindholm [31], a structural dip of less than $25^{\circ}$ needs no correction.

\section{Results}

\subsection{Geochemical analysis}

The major oxide concentration for the sandstone and clay samples are presented in Tables 1 and 2, respectively. It is observed that the $\mathrm{SiO}_{2}$ content in sandstones (52.47-84.18 wt\%) is higher than in clays
(17.10-59.51 wt\%). In contrasts, the clays have higher $\mathrm{Al}_{2} \mathrm{O}_{3}$ content (4.03-27.79 wt\%) with respect to sandstones (7.21-17.77 wt\%). Similarly, the $\mathrm{Fe}_{2} \mathrm{O}_{3}$ content in clays with an average concentration of $6.46 \mathrm{wt} \%$ is high as compare to sandstones (avg. $2.2 \mathrm{wt} \%$ ). $\mathrm{CaO}, \mathrm{MgO}$ and $\mathrm{TiO}_{2}$ contents in sandstones range from 8.70 to $9.64 \mathrm{wt} \%$, 0.25 to 0.36 wt $\%$ and 0.33 to 0.86 wt $\%$, respectively. In clays the $\mathrm{CaO}$ (8.71-9.89 wt\%) and $\mathrm{TiO}_{2}(0.72-6.68$ wt\%) contents are slightly higher than in sandstones while $\mathrm{MgO}(0.23-0.37 \mathrm{wt} \%)$ contents are lower. The $\mathrm{K}_{2} \mathrm{O}$ contents in both the sandstones and clays are very low, ranging from 0.00 to $0.02 \mathrm{wt} \%$ and 0.00 to $0.90 \mathrm{wt} \%$, respectively. The $\mathrm{K}_{2} \mathrm{O}$ concentration was not detected in nine (9) and six (6) sandstones and clays samples. $\mathrm{Na}_{2} \mathrm{O}$ 
Fig. 4 Maps of the two studied areas showing the sampling locations: a locality 1 (Gombe Abba) and b locality 2 (Akko)
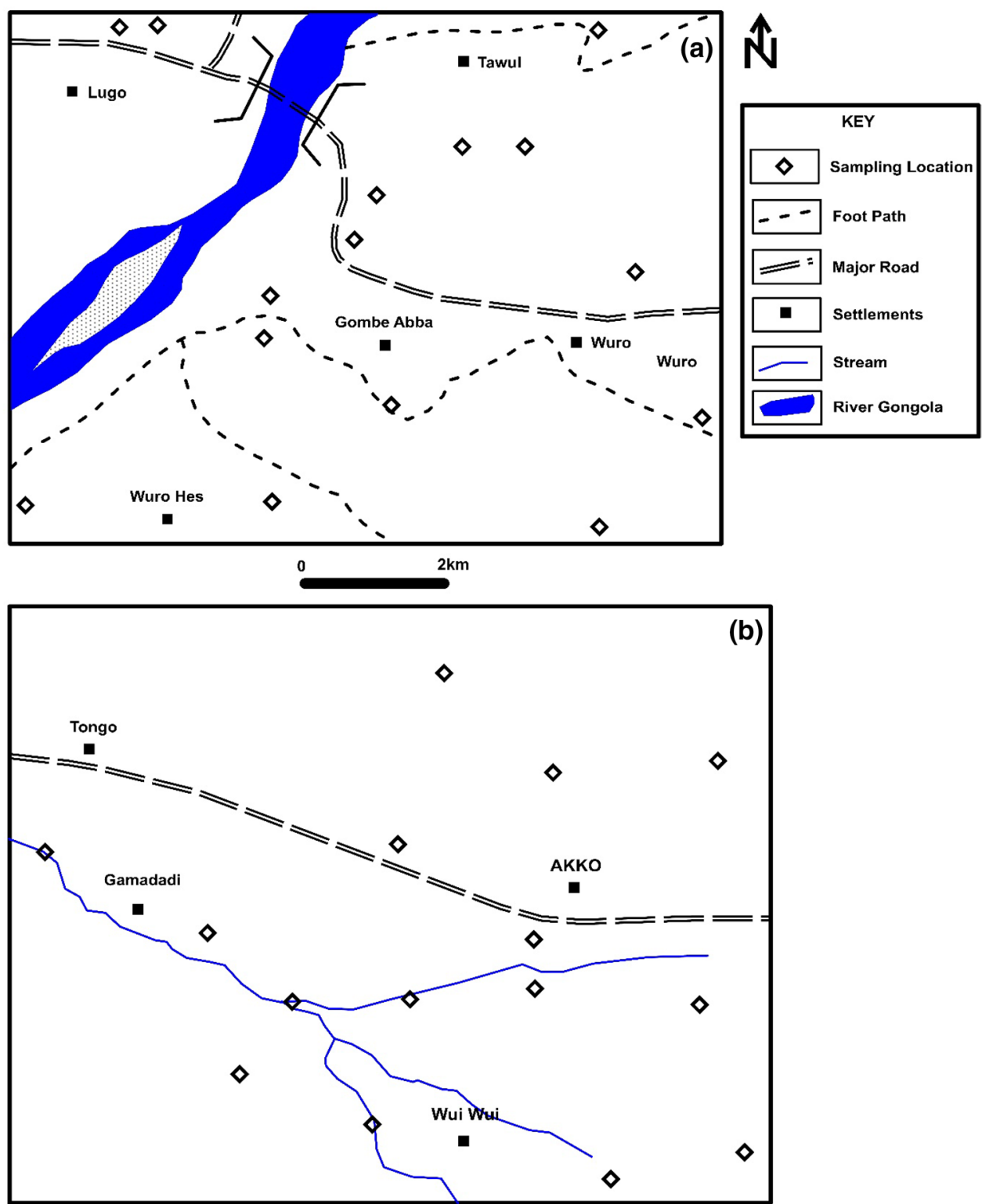

content in sandstones ranges from 0.07 to $0.09 \mathrm{wt} \%$ with an average value of 0.08 wt $\%$ and from 0.07 to 0.13 wt $\%$ in clays.

The sandstones are plotted in the litharenite field while the clay samples are scattered within the greywacke field on the Pettijohn et al. [32] geochemical classification diagram $\left(\log \mathrm{Na}_{2} \mathrm{O} / \mathrm{K}_{2} \mathrm{O}\right.$ vs. $\log \mathrm{SiO}_{2} / \mathrm{Al}_{2} \mathrm{O}_{3}$ ) (Fig. 5).

\subsection{Palaeocurrent data}

The palaeocurrent data obtained was tabulated in the form of a simple statistical frequency table (Tables 3, 4 and 5 for stream 1, 2 and 3 , respectively). A class of $30^{\circ}$ was used to group the data and the total number and percentage of observation for each class interval was calculated. The modal class intervals are between 241 and 270 $(n=11)$ in stream 1 (Table 3$)$ and stream $2(n=17$; Table 4). However, the modal class interval ranges from 211 to 240 $(n=15)$ in stream 3 (Table 5). Rose diagrams, plotted to identify palaeocurrent trends using Rose.Net software, show that the arithmetic mean of stream 1, 2 and 3 are $237^{\circ}, 268^{\circ}$, and $232^{\circ}$, respectively, displaying a unimodal fan shape diagram (Fig. 6).

\section{Discussion}

\subsection{Statistical analysis}

The geochemical data was subjected to statistical correlation analysis with the aim to understand the most highly correlated element pairs within the major oxides. For this 
Table 1 Chemical composition of major elements of the sandstones of the Kerri-Kerri Formation

\begin{tabular}{|c|c|c|c|c|c|c|c|c|c|c|c|c|c|c|c|}
\hline Oxides & AS 1 & AS 2 & AS 3 & AS 4 & AS 5 & AS 6 & AS 7 & AS 8 & AS 9 & AS 10 & GS1 & GS2 & GS3 & GS4 & GS5 \\
\hline $\mathrm{O}_{2}$ & .65 & 6 & 1 & 73.73 & 83.10 & 84.18 & 76.70 & 63.68 & 1.01 & 80.58 & 64.87 & 52.47 & 61.34 & 6 & 67.80 \\
\hline $\mathrm{Al}_{2} \mathrm{O}_{3}$ & 9.54 & 8.54 & 9.86 & 10.66 & 7.65 & 7.21 & 9.70 & 7.57 & 11.81 & 15 & 8.88 & 17.77 & 15.50 & 10.82 & 8.87 \\
\hline $\mathrm{e}_{2} \mathrm{O}_{3}$ & 2.39 & 1.86 & 1.68 & 1.47 & 1.65 & 1.91 & 1.53 & 1.56 & 1.54 & 1.49 & 4.84 & 2.06 & 2.34 & 2.35 & 4.28 \\
\hline $\mathrm{aO}$ & 9.02 & 8.82 & 9.64 & 9.17 & 8.82 & 8.90 & 8.94 & 8.97 & 8.96 & 9.57 & 9.06 & 8.70 & 8.81 & 9.06 & 9.32 \\
\hline $\operatorname{lgO}$ & נב. & 0.32 & 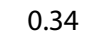 & 0.36 & 0.31 & 0.33 & 0.32 & 0.33 & 0.31 & 0.33 & 0.33 & 0.25 & 0.27 & 0.29 & 0.32 \\
\hline $\mathrm{SO}_{3}$ & 60 & 0.6 & 0.60 & 0.60 & 0.60 & 0.60 & 0.60 & 0.60 & 0.60 & 0.60 & 0.63 & 0.60 & 0.62 & 0.63 & 0.62 \\
\hline $\mathrm{K}_{2} \mathrm{O}$ & .00 & 0.00 & 0.00 & 0.00 & 0.00 & 0.00 & 0.00 & 0.00 & 0.06 & 0.00 & 0.05 & 0.04 & .01 & .05 & 0.04 \\
\hline $\mathrm{Na}_{2} \mathrm{O}$ & 0.08 & 0.08 & 0.08 & 0.07 & 0.08 & 0.07 & 0.08 & 0.07 & 0.07 & 0.07 & 0.08 & 0.08 & 0.09 & 0.08 & 0.09 \\
\hline $\mathrm{P}_{2} \mathrm{O}_{5}$ & 0.00 & 0.00 & 0.00 & 0.05 & 0.00 & 0.00 & 0.00 & 0.00 & 0.00 & 0.00 & 0.14 & 0.01 & 0.02 & 0.02 & 0.04 \\
\hline $\mathrm{Mn}_{2} \mathrm{O}_{3}$ & 0.01 & 0.0 & 0 & 0.01 & 0.01 & 0.01 & 0.01 & 0.01 & 0.01 & 0.02 & 0.04 & 0.02 & 0.02 & 0.01 & 0.03 \\
\hline $\mathrm{TiO}_{2}$ & 0.55 & 0.37 & 0.34 & 0.47 & 0.35 & 0.33 & 0.62 & 0.41 & 0.40 & 0.72 & 2.27 & 1.67 & 2.59 & 0.78 & 1.05 \\
\hline LOI & 7.47 & 7.28 & 7.94 & 7.59 & 7.26 & 7.34 & 7.36 & 7.40 & 7.36 & 80 & 7.46 & 1.1 & 7.22 & 7.43 & 7.67 \\
\hline $\mathrm{SiO}_{2} / \mathrm{Al}_{2} \mathrm{O}_{3}$ & 7.82 & 9.57 & 7.22 & 6.92 & 10.86 & 11.68 & 7.91 & .41 & 6.01 & 89 & 7.31 & 2.95 & 3.96 & 6.66 & 7.64 \\
\hline $\mathrm{Al}_{2} \mathrm{O}_{3} / \mathrm{TiO}_{2}$ & 17.35 & 23.0 & 29.00 & 22.68 & 21.86 & 21.85 & 15.65 & 18.46 & 29.53 & 11.32 & .91 & 10.64 & 5.98 & 13.87 & 8.45 \\
\hline $\mathrm{ClA}$ & 51.19 & 48.99 & 50.38 & 53.56 & 46.22 & 44.57 & 51.82 & 45.57 & 56.51 & 45.81 & 49.16 & 66.83 & 63.50 & 54.07 & 48.42 \\
\hline m & 51.19 & 48.99 & 50.38 & 53.56 & 46.22 & 44.57 & 51.82 & 45.57 & 56.54 & 45.81 & 49.29 & 66.93 & 63.52 & 54.21 & 48.52 \\
\hline CIW & 51.99 & 48.99 & 50.38 & 53.56 & 46.22 & 44.57 & 51.82 & 45.57 & 56.67 & 45.81 & 49.45 & 67.18 & 63.96 & 54.39 & 48.78 \\
\hline ICV & .30 & 1.34 & 1.23 & 1.08 & 1.47 & 1.60 & 1.19 & 1.50 & 0.96 & 1.50 & 1.88 & 0.72 & 0.91 & 1.17 & 1.71 \\
\hline
\end{tabular}

Table 2 Chemical composition of major elements of the clays of the Kerri-Kerri Formation

\begin{tabular}{|c|c|c|c|c|c|c|c|c|c|c|c|c|c|c|c|}
\hline Oxides (wt\%) & AC 1 & $A C 2$ & $A C 3$ & AC 4 & AC 5 & GC1 & $\mathrm{GC2}$ & GC3 & GC4 & GC5 & GC6 & GC7 & GC8 & GC9 & $\mathrm{GC1}$ \\
\hline $\mathrm{O}_{2}$ & 47.14 & 56.63 & 50.86 & 50.42 & 87.21 & 49.70 & 36.60 & 59.51 & 18.80 & 43.57 & 36.04 & 42.66 & 43.38 & 17.10 & 44.93 \\
\hline $\mathrm{I}_{2} \mathrm{O}_{3}$ & 20.18 & 16.88 & 17.33 & 19.11 & 4.03 & 20.81 & 27.79 & 12.92 & 13.17 & 20.68 & 24.81 & 21.83 & 22.68 & 9.44 & 19.05 \\
\hline $\mathrm{e}_{2} \mathrm{O}_{3}$ & 3.31 & 2.92 & 3.16 & 3.12 & 1.92 & 2.09 & 1.97 & 2.47 & 27.36 & 2.88 & 2.87 & 2.58 & 3.71 & 32.88 & 3.68 \\
\hline $\mathrm{aO}$ & 9.17 & 9.09 & 9.56 & 8.92 & 9.89 & 9.00 & 9.27 & 8.75 & 9.03 & 9.04 & 9.60 & 9.40 & 8.83 & 8.78 & 8.71 \\
\hline $\operatorname{lgO}$ & 0.33 & 0.31 & 0.35 & 0.30 & 0.37 & 0.27 & 0.24 & 0.30 & 0.31 & 0.28 & 0.27 & 0.26 & .23 & 0.30 & 0.24 \\
\hline $\mathrm{SO}_{3}$ & 60 & 0.64 & 0.61 & 0.60 & 0.60 & 0.61 & 0.61 & 0.62 & 0.63 & 0.61 & 0.67 & 0.62 & 0.61 & 0.63 & 0.61 \\
\hline $\mathrm{K}_{2} \mathrm{O}$ & .00 & 0.00 & 0.01 & 0.00 & 0.00 & 0.08 & 0.09 & 0.05 & 0.00 & 0.02 & 0.06 & 0.00 & 0.01 & 0.04 & 0.02 \\
\hline $\mathrm{Na}_{2} \mathrm{O}$ & 0.10 & 0.07 & 0.08 & 0.08 & 0.08 & 0.08 & 0.13 & 0.08 & 0.09 & 0.08 & 0.08 & 0.08 & 0.07 & 0.08 & 0.07 \\
\hline $\mathrm{P}_{2} \mathrm{O}_{5}$ & 0.01 & 0.00 & 0.03 & 0.03 & 0.01 & 0.02 & 0.04 & 0.05 & 0.22 & 0.05 & 0.10 & 0.07 & 0.09 & 0.11 & 0.09 \\
\hline $\mathrm{Mn}_{2} \mathrm{O}_{3}$ & 0.02 & 0.02 & 0.03 & 0.02 & 0.03 & 0.02 & 0.02 & 0.04 & 0.22 & 0.05 & 0.03 & 0.03 & 0.03 & 0.12 & 0.02 \\
\hline $\mathrm{TiO}_{2}$ & 0.72 & 1 & 2 & 2 & 0 & 2 & 3 & 5.08 & 41 & 6.68 & 5 & 5.07 & 6 & 8 & 4.21 \\
\hline LOI & 7.80 & 7. & 7 & 7.33 & 8 & 6 & 4 & 7.20 & 7.43 & 7.40 & 7.83 & 7.66 & 7.18 & 7.23 & 7.10 \\
\hline $\mathrm{SiO}_{2} / \mathrm{Al}_{2} \mathrm{O}_{3}$ & 2.34 & 3.35 & 2.93 & 2.64 & 21.64 & 2.39 & 1.32 & 4.61 & 1.43 & 2.11 & 1.45 & 1.95 & 1.91 & 1.81 & 2.36 \\
\hline $\mathrm{Al}_{2} \mathrm{O}_{3} / \mathrm{TiO}_{2}$ & 28.03 & 14.94 & 6.69 & 7.41 & 4.11 & 10.84 & 13.69 & 2.54 & 2.99 & 3.10 & 4.59 & 4.31 & 4.31 & 2.97 & 4.52 \\
\hline $\mathrm{CIA}$ & 68.53 & 64.81 & 45.81 & 67.98 & & 69.44 & 74.54 & 59.26 & 59.08 & 69.34 & 71.81 & 69.71 & 71.79 & 51.47 & 68.41 \\
\hline PIA & 68.53 & 64.81 & 45.81 & 67.98 & 28.78 & 69.63 & 74.72 & 59.40 & 59.08 & 69.39 & 71.93 & 69.72 & 71.82 & 51.58 & 68.45 \\
\hline CIW & 68.53 & 64.81 & 45.81 & 67.98 & 28.78 & 69.73 & 75.00 & 59.61 & 59.56 & 69.70 & 72.09 & 70.07 & 72.09 & 51.81 & 68.73 \\
\hline ICV & 0.68 & 0.80 & 0.91 & 0.79 & 3.29 & 0.65 & 0.49 & 1.30 & 3.15 & 0.92 & 0.74 & 0.80 & 0.80 & 4.81 & 0.89 \\
\hline
\end{tabular}

study, correlation matrix was generated using Pearson product moment coefficient of correlation method [29] and the result is shown in Table $6 . \mathrm{SiO}_{2}$ shows a strong negative correlation with $\mathrm{Al}_{2} \mathrm{O}_{3}, \mathrm{Fe}_{2} \mathrm{O}_{3}, \mathrm{SO}_{3}, \mathrm{P}_{2} \mathrm{O}_{5}, \mathrm{Mn}_{2} \mathrm{O}_{3}$, and $\mathrm{TiO}_{2}$, indicating that bulk of $\mathrm{SiO}_{2}$ is controlled by the quartz grains [3]. Significant correlation was observed between $\mathrm{Al}_{2} \mathrm{O}_{3}$ with $\mathrm{K}_{2} \mathrm{O}, \mathrm{Na}_{2} \mathrm{O}$ and $\mathrm{TiO}_{2}$, suggesting their associations with aluminous clay minerals $[3,33,34]$. $\mathrm{CaO}$ exhibits significant correlation with $\mathrm{MgO}$ and $\mathrm{LO}$, which suggest their relation with carbonate minerals [3]. In contrast, $\mathrm{MgO}$ shows negative correlation with $\mathrm{K}_{2} \mathrm{O}$ and $\mathrm{TiO}_{2}$, indicating that $\mathrm{K}_{2} \mathrm{O}$ and $\mathrm{TiO}_{2}$ are not associated with carbonate minerals (dolomite) [4]. Significant correlation 
Fig. 5 Geochemical classification diagram using log $\mathrm{Na2O} /$ $\mathrm{K} 2 \mathrm{O}$ versus log $\mathrm{SiO} 2 / \mathrm{Al} 2 \mathrm{O} 3$ (after Pettijohn et al. [32])

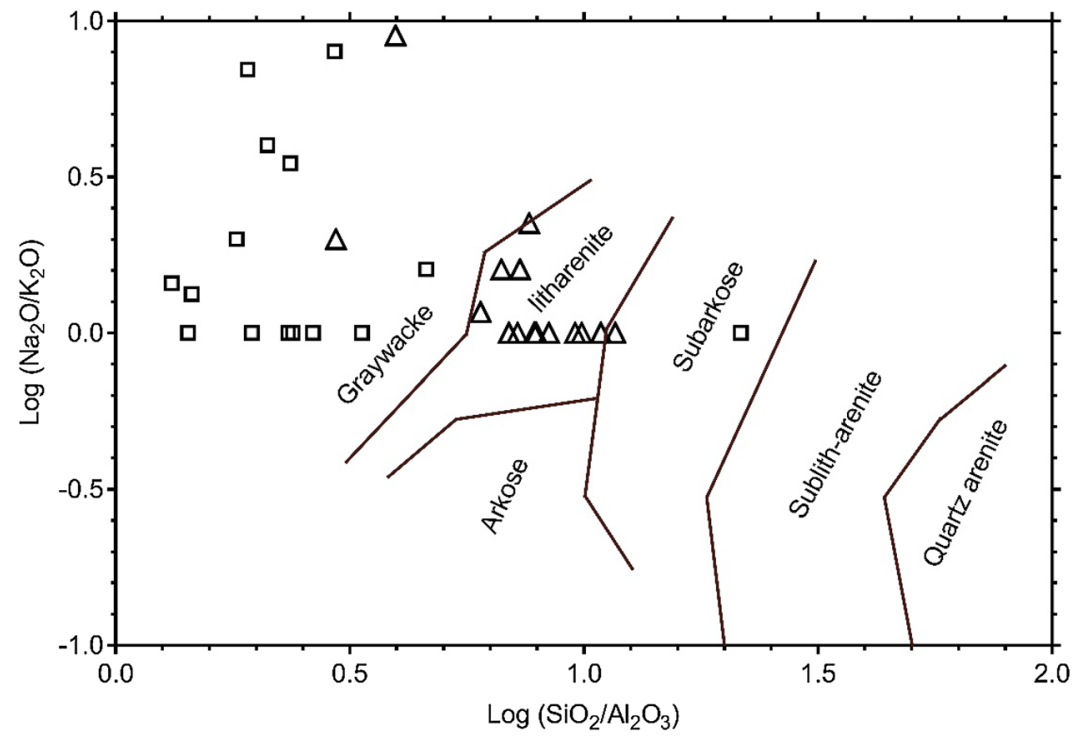

$\triangle$ Sandstone

口 Clay
Table 3 Palaeocurrent data of stream 1

\begin{tabular}{llcc}
\hline S/N & Class $\left(^{\circ}\right)$ & Frequency & Percentage \\
\hline 1 & $180-210$ & 3 & 10 \\
2 & $211-240$ & 10 & 33 \\
3 & $241-270$ & 11 & 37 \\
4 & $271-300$ & 6 & 20 \\
5 & $301-330$ & 0 & 0 \\
6 & $331-360$ & 0 & 0 \\
& & 30 & 100 \\
\hline
\end{tabular}

Table 4 Palaeocurrent data of stream 2

\begin{tabular}{llcc}
\hline S/N & Class $\left(^{\circ}\right)$ & Frequency & Percentage \\
\hline 1 & $180-210$ & 0 & 0 \\
2 & $211-240$ & 0 & 0 \\
3 & $241-270$ & 17 & 57 \\
4 & $271-300$ & 6 & 20 \\
5 & $301-330$ & 7 & 23 \\
6 & $331-360$ & 0 & 0 \\
& & 30 & 100 \\
\hline
\end{tabular}

exists between $\mathrm{Na}_{2} \mathrm{O}$ and $\mathrm{K}_{2} \mathrm{O}$, indicating their association with plagioclase feldspar [4].

\subsection{Sediment maturity}

The ratio of $\mathrm{SiO}_{2} / \mathrm{Al}_{2} \mathrm{O}_{3}$ is an important indicator of textural maturity of sediments [35-37]. Average $\mathrm{SiO}_{2} / \mathrm{Al}_{2} \mathrm{O}_{3}$ value in unaltered igneous rocks range from 3.0 (basic rocks) to 5.0 (acidic rocks). $\mathrm{SiO}_{2} / \mathrm{Al}_{2} \mathrm{O}_{3}$ values $>5.0$ in clastic sediments indicate high sediment maturity. The studied sandstones
Table 5 Palaeocurrent data of stream 3

\begin{tabular}{llcc}
\hline S/N & Class $\left(^{\circ}\right)$ & Frequency & Percentage \\
\hline 1 & $151-180$ & 4 & 13 \\
2 & $181-210$ & 3 & 10 \\
3 & $211-240$ & 15 & 50 \\
4 & $241-270$ & 6 & 20 \\
5 & $271-300$ & 2 & 7 \\
6 & $301-330$ & 0 & 0 \\
7 & $331-360$ & 0 & 0 \\
& & 30 & 100 \\
\hline
\end{tabular}

have $\mathrm{SiO}_{2} / \mathrm{Al}_{2} \mathrm{O}_{3}$ value range from 2.95 to 11.68 with an average of 7.65 (Table 1), while the clay samples (excluding AC5) have $\mathrm{SiO}_{2} / \mathrm{Al}_{2} \mathrm{O}_{3}$ value range from 1.32 to 4.61 with an average of 2.33. These indicate that the sandstones samples are compositionally matured whereas the clay samples are compositionally immature.

Similarly, Index of Compositional Variation (ICV) of Cox et al. [38] was calculated for all the studied samples in order to also identify their compositional maturity. Nagarajan et al. [3] and Tawfik et al. [35] have successfully used ICV to identify the composition maturity of clastic sediments. In the sandstones of the Kerri-Kerri Formation, the ICV values ranges from 0.72 to 1.87 with an average of 1.30 (Table 1), indicating that these sandstones are compositionally submature to mature [3]. However, the clay samples have ICV values from 0.49 to 4.81 (avg. 1.40) (Table 2), suggesting they are compositional immature to submature [38]. 


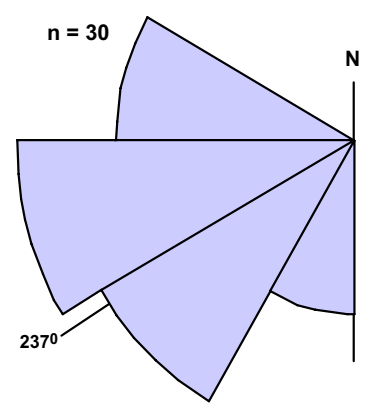

(a)

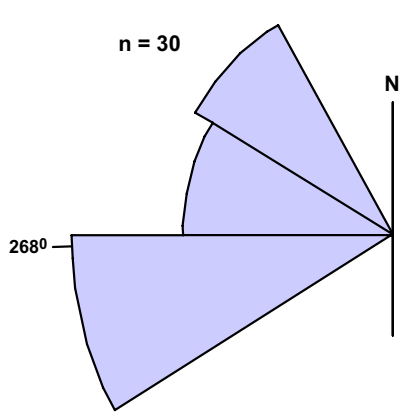

(b)

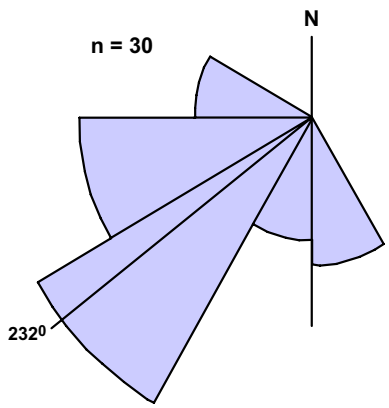

(c)

Fig. 6 Rose diagrams a stream 1, b stream 2, c stream 3

Table 6 Correlation matrices for the geochemical data in Tables 1 and 2

\begin{tabular}{|c|c|c|c|c|c|c|c|c|c|c|c|c|}
\hline & $\mathrm{SiO}_{2}$ & $\mathrm{Al}_{2} \mathrm{O}_{3}$ & $\mathrm{Fe}_{2} \mathrm{O}_{3}$ & $\mathrm{CaO}$ & $\mathrm{MgO}$ & $\mathrm{SO}_{3}$ & $\mathrm{~K}_{2} \mathrm{O}$ & $\mathrm{Na}_{2} \mathrm{O}$ & $\mathrm{P}_{2} \mathrm{O}_{5}$ & $\mathrm{Mn}_{2} \mathrm{O}_{3}$ & $\mathrm{TiO}_{2}$ & LOI \\
\hline $\mathrm{SiO}_{2}$ & 1 & & & & & & & & & & & \\
\hline $\mathrm{Al}_{2} \mathrm{O}_{3}$ & -0.608 & 1 & & & & & & & & & & \\
\hline $\mathrm{Fe}_{2} \mathrm{O}_{3}$ & -0.640 & -0.093 & 1 & & & & & & & & & \\
\hline $\mathrm{CaO}$ & 0.026 & -0.024 & -0.179 & 1 & & & & & & & & \\
\hline $\mathrm{MgO}$ & 0.465 & -.743 & -0.023 & 0.404 & 1 & & & & & & & \\
\hline $\mathrm{SO}_{3}$ & -0.524 & 0.301 & 0.337 & 0.110 & -0.288 & 1 & & & & & & \\
\hline $\mathrm{K}_{2} \mathrm{O}$ & -0.297 & 0.386 & 0.028 & -0.075 & -0.467 & 0.366 & 1 & & & & & \\
\hline $\mathrm{Na}_{2} \mathrm{O}$ & -0.343 & 0.403 & 0.097 & 0.139 & -0.228 & 0.063 & 0.394 & 1 & & & & \\
\hline $\mathrm{P}_{2} \mathrm{O}_{5}$ & -0.717 & 0.232 & 0.681 & -0.072 & -0.268 & 0.550 & 0.173 & 0.108 & 1 & & & \\
\hline $\mathrm{Mn}_{2} \mathrm{O}_{3}$ & -0.645 & 0.005 & 0.888 & -0.071 & -0.043 & 0.362 & -0.007 & 0.155 & 0.804 & 1 & & \\
\hline $\mathrm{TiO}_{2}$ & -0.680 & 0.609 & 0.278 & -0.087 & -0.593 & 0.488 & 0.199 & 0.037 & 0.647 & 0.436 & 1 & \\
\hline LOI & 0.063 & -0.097 & -0.162 & 0.972 & 0.537 & 0.041 & -0.157 & 0.159 & -0.118 & -0.073 & -0.186 & 1 \\
\hline
\end{tabular}

\subsection{Palaeoweathering}

Chemical index of alteration (CIA) [39], plagioclase index of alteration (PIA) [33] and chemical index of weathering (CIW) [40] were used to assess the palaeoweathering conditions of the Kerri-Kerri Formation sediments. These indices of weathering/alteration (CIA, PIA, and CIW) have been successfully used by several workers as a tool to interpret the chemical weathering conditions in the source area $[3$, $35,36]$.

According to Nesbitt and Young [39] and Fedo et al. [33], $\mathrm{ClA}$ value $>80$ indicates intense chemical weathering whereas value $<50$ indicates low or weak weathering stage. The CIA values of the Kerri-Kerri Formation sandstone and clay samples range from 44.57 to 66.83 with an average of 51.77 and 45.81 to 74.54 with an average of 65.14 , respectively (Table 1; Fig. 7), suggesting low to moderate chemical weathering in the source area. The CIW and PIA values of sandstones vary from 44.57 to 67.18 and 44.57 to 66.93 , respectively (Table 1 ), while the clays have average CIW and PIA values of 62.78 and 62.95 , respectively (Table 2). The average CIW and PIA values of the studied samples (Tables 1,2) also indicate low to moderate chemical weathering in the source area [33,39].

On the A-CN-K diagram (Fig. 7), the Kerri-Kerri sandstones plot close to the plagioclase composition whereas most of clays were plotted closer to the Smectite away from the plagioclase. Both the sandstones and the clays are clustered along A-CN line. The clustering of the studied sediments along the A-CN line indicates leaching of $\mathrm{Na} 2 \mathrm{O}, \mathrm{CaO}$ and $\mathrm{K} 2 \mathrm{O}$ in feldspars during chemical weathering in the source area of the Kerri-Kerri Formation sediments $[3,11,35,41]$.

\subsection{Provenance}

Roser and Korsch [42] provenance discrimination function diagram is used to infer the provenance of the studied sediments. On this diagram, the Kerri-Kerri sandstones plot in the quartzose sedimentary provenance whereas the clays plot mainly in the quartzose 

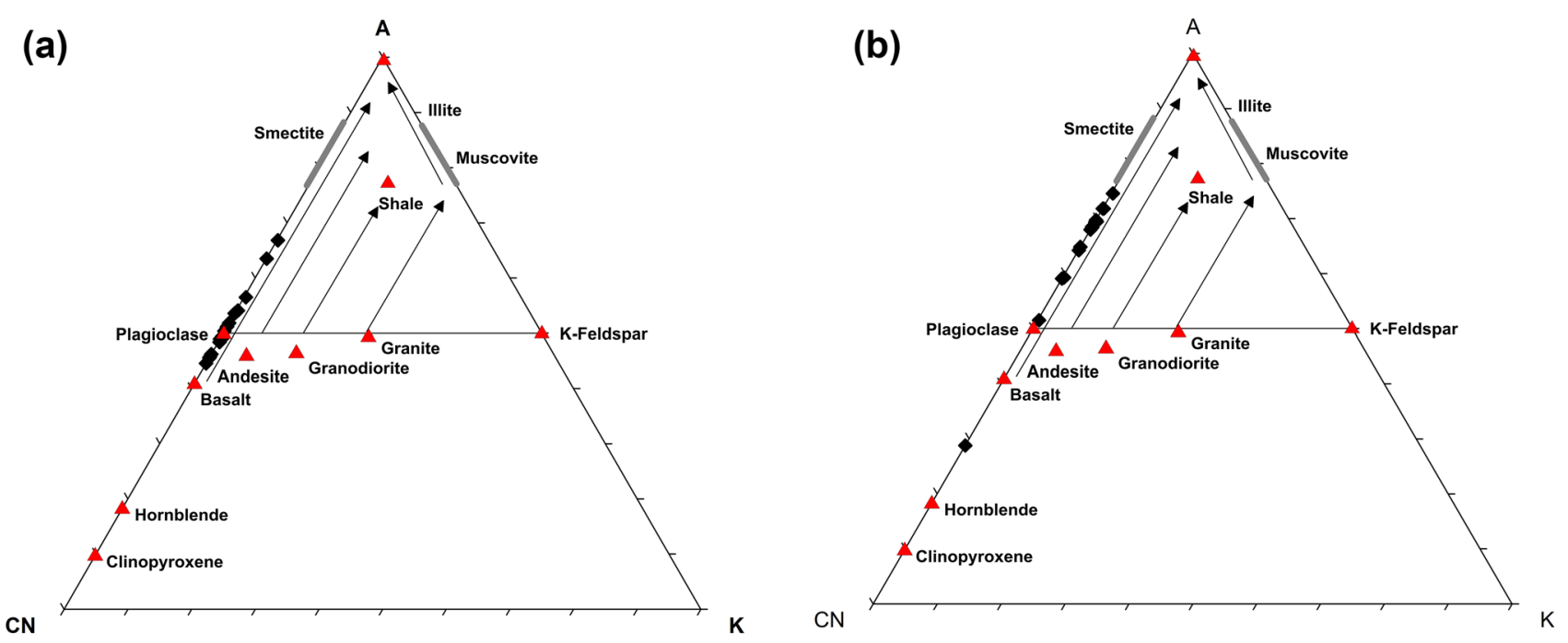

Fig. 7 A-CN-K plots (after Nesbitt and Young [39]) showing the weathering trend for the siliciclastic sediments of the a Kerri-Kerri sandstones and b Kerri-Kerri clays

Fig. 8 Major element based provenance discriminant function plot for the Kerri-Kerri Formation (after Roser and Korsch [42])

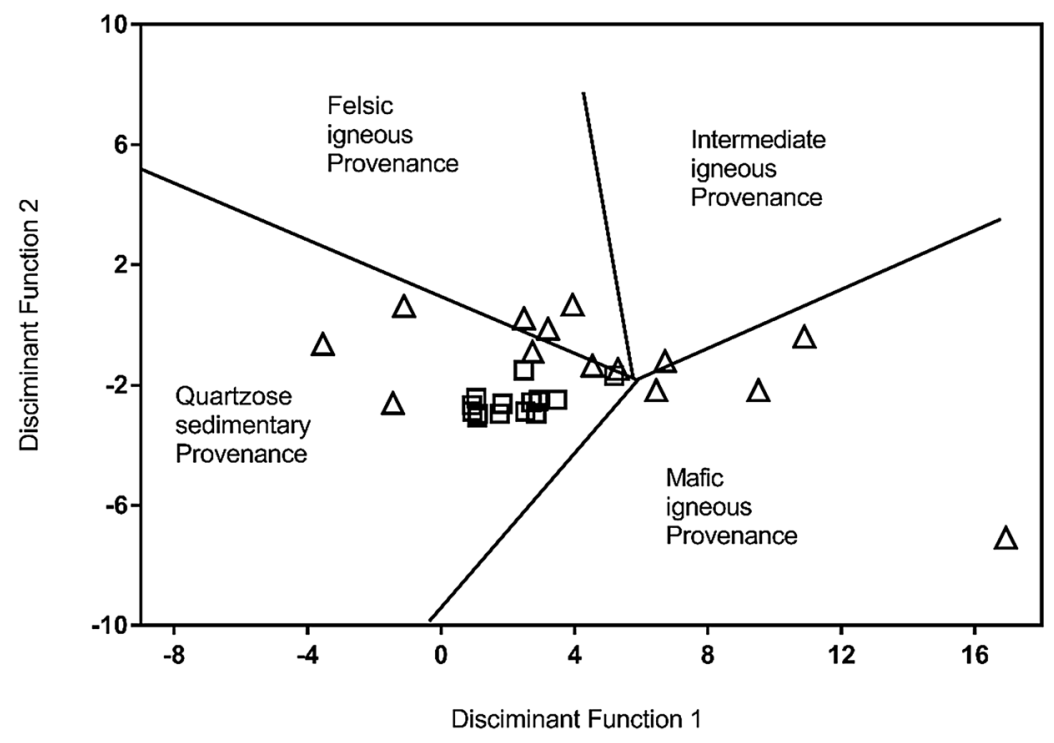

$\square$ Sandstone

$\Delta$ Clay sedimentary and felsic igneous provenances (Fig. 8). These suggest that the Kerri-Kerri Formation sediments were dominantly derived from pre-existing sedimentary rocks with little influence from felsic igneous rocks.

\subsection{Tectonic setting}

Researches have been carried out by various workers on the use of major elements content of sedimentary rocks to determine the tectonic settings of their source area $[5,8$, $11,42,43]$. Major-element based discrimination diagram proposed by Verma and Armstrong Altrin [43] is used to infer the tectonic setting of the provenance area of the Kerri-Kerri Formation sediments. The diagram is divided into three main tectonic fields: island or continental arc, continental rift, and collision [43]. On the discrimination diagram (Fig. 9), the studied sediments are plotted in the rift field, suggesting a passive margin derived sediments, which is in agreement with the geology of the Benue Trough [13].

\subsection{Palaeocurrent interpretation}

The palaeocurrent data are diagrammatically presented on a rose diagram (Fig. 6). The rose diagrams (Fig. 6) show that the Kerri-Kerri Formation sediments were deposited by dominantly south-westerly palaeocurrent trend. This suggests that the sediments were sourced from north-eastern 
Fig. 9 Tectonic setting discriminant-function for the KerriKerri Formation (after Verma and Armstrong-Altrin [43])

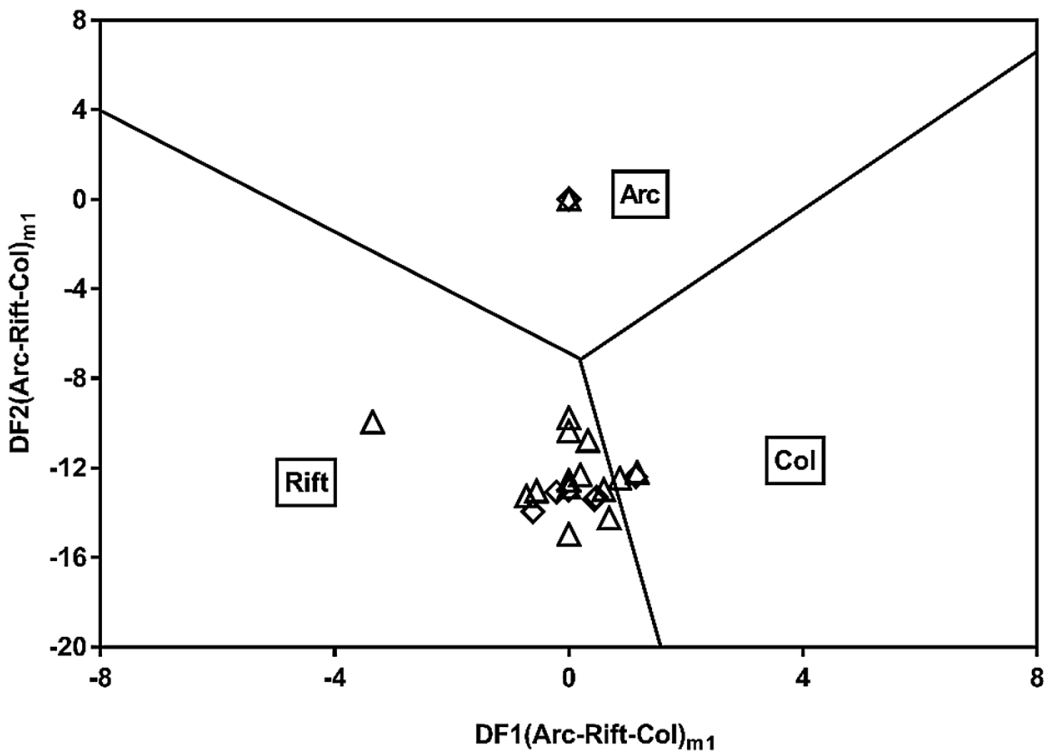

$\diamond$ Sandstone

$\Delta$ Clay direction possibly from pre-existing Cretaceous sedimentary rocks of the Gongola Sub-Basin with little influence from felsic igneous rocks of the North Eastern Nigeria.

\section{Conclusion}

Geochemical and palaeocurrent data have been used to constrain the provenance, tectonic setting, and source area palaeoweathering conditions of the Kerri-Kerri Formation clastic sediments (sandstones and clays) in the Gongola Sub-Basin, Northern Benue Trough, Nigeria. Based on major element compositions, the sandstones and clays are classified as litharenite and greywacke, respectively. The ratio of $\mathrm{SiO}_{2} / \mathrm{Al}_{2} \mathrm{O}_{3}$ and $\mathrm{ICV}$ indicate that the sandstones are compositionally matured while the clays are immature. The values of CIA, PIA, and CIW indicate low to moderate chemical weathering in the source area of the formation. The provenance discrimination function diagram revealed that the Kerri-Kerri sandstones are sourced from quartzose sedimentary provenance whereas the clays from quartzose sedimentary and felsic igneous rocks. Major-element based tectonic setting discrimination diagram suggest passive margin tectonic setting (rift) for the sediments of the Kerri-Kerri Formation and is in agreement with the geology of the Benue Trough. We conclude that, the sediments of the Kerri-Kerri Formation were sourced from pre-existing Cretaceous sedimentary rocks of the Gongola Sub-Basin with little influence from felsic igneous rocks of north eastern Nigeria. And probably deposited by dominantly south-westerly palaeocurrent trend from source rocks in the north eastern direction.
Acknowledgements The authors extend their appreciation to Lafarge Holcim Plc (Ashaka Cement), Gombe Nigeria for carrying out the geo chemical analysis. Our appreciation is further expressed to anonymous reviewer for reviewing the manuscript and making critical comments and valuable suggestions.

\section{Compliance with ethical standards}

Conflict of interest The authors affirm that there is no conflict of interest.

Ethical standards This study is in full compliance with all applicable ethical standards.

\section{References}

1. Wang W, Zhou M-F (2013) Petrological and geochemical constraints on provenance, paleoweathering, and tectonic setting of the neoproterozoic sedimentary basin in the eastern Jiangnan orogen, south China. J Sediment Res. https://doi. org/10.2110/jsr.2013.74

2. Smyth HR, Morton A, Richardson N, Scott RA (2014) Sediment provenance studies in hydrocarbon exploration and production: an introduction. In: Scott RA, Smyth HR, Morton AC, Richardson $\mathrm{N}$ (eds) Sediment provenance studies in hydrocarbon exploration and production, vol 386. Geological Society of London Special Publications, pp 1-6. https://doi.org/10.1144/SP386.21

3. Nagarajan R, Armstrong-Altrin JS, Kessler FL, Jong J (2017) Petrological and geochemical constraints on provenance, paleoweathering, and tectonic setting of clastic sediments from the Neogene Lambir and Sibuti Formations, northwest Borneo. In: Mazumder R (ed) Sediment provenance influences on compositional change from source to sink. Elsevier Inc., New York, pp 123-153. https://doi.org/10.1016/B978-0-12-803386-9.00007-1

4. Tawfik HA, Ghandour IM, Maejima W, Armstrong-Altrin JS, Abdel-Hameed AT (2015) Petrography and geochemistry of the siliciclastic Araba Formation (Cambrian), east Sinai, Egypt: 
implications for provenance, tectonic setting and source weathering. Geol Mag. https://doi.org/10.1017/S0016756815000771

5. Armstrong-Altrin JS, Lee YI, Kasper-Zubillaga JJ, Trejo-Ramírez E (2016) Mineralogy and geochemistry of sands along the Manzanillo and El Carrizal beaches, southern Mexico: implications for provenance and tectonic setting. Geol J. https://doi. org/10.1002/gj.2792

6. Schneider S, Hornung J, Hinderer M (2017) Evolution of the northern Albertine Rift reflected in the provenance of synrift sediments (Nkondo-Kaiso area, Uganda). J Afric Earth Sci 131:183-197

7. Bhatia MR (1983) Plate tectonics and geochemical compositions of sandstones. J Geol 91:611-627

8. Bhatia MR (1985) Composition and classification of flysch mudrocks of Eastern Australia: implication in provenance and tectonic setting interpretation. Sediment Geol 41:249-268

9. Bhatia MR, Crook KAW (1986) Trace element characteristics of Graywackes and tectonic setting discrimination of sedimentary basins. Contrib Miner Petrol 92:181-193

10. Roser BP, Korsch RJ (1986) Determination of tectonic setting of sandstone-mudstone suites using $\mathrm{SiO}_{2}$ content and $\mathrm{K}_{2} \mathrm{O} / \mathrm{Na}_{2} \mathrm{O}$ ratio. J Geol 94:635-650

11. Khan T, Khan MS (2015) Clastic rock geochemistry of Punagarh basin, trans-Aravalli region, NW Indian shield: implications for paleoweathering, provenance, and tectonic setting. Arab J Geosci 8:3621-3644

12. Armstrong-Altrin JS (2015) Evaluation of two multi-dimensional discrimination diagrams from beach and deep sea sediments from the Gulf of Mexico and their application to Precambrian clastic sedimentary rocks. Int Geol Rev 57:1446-1461

13. Nwajide CS (2013) Geology of Nigeria's sedimentary basins. CSS Bookshops Ltd, Lagos

14. Dike EFC (1993) Stratigraphy and structure of the Kerri-Kerri Basin, north-eastern Nigeria. J Min Geol 29:77-93

15. Adegoke OS, Agumanu AE, Benkhelil MJ, Ajayi PO (1986) New stratigraphic, sedimentologic and structural data on the KerriKerri Formation, Bauchi and Borno States, Nigeria. J Afric Earth Sci 5:249-277

16. Carter JD, Barber WDF, Tait EA (1963) The geology of parts of Adamawa, Bauchi and Bornu provinces in north-eastern Nigeria. In: Geological Survey of Nigeria Bulletin, vol 30

17. Adegoke OS, Jan Du Chene RE, Agumanu AE, Ajayi PO (1978) Palaenology and age of the Kerri-Kerri Formation, Nigeria. Rev Espan Micropaleontol 2:267-283

18. Benkhelil J (1989) The origin and evolution of the Cretaceous Benue Trough (Nigeria). J Afric Earth Sci 8:251-282

19. Abubakar MB (2014) Petroleum potentials of the Nigerian Benue Trough and Anambra Basin: a regional synthesis. Nat Resour 5:25-58

20. Zaborski PM, Ugodulunwa F, Idornigie A, Nnabo P, Ibe K (1997) Stratigraphy and structure of the Cretaceous Gongola Basin, northeast Nigeria. Bull Centres Rec Explor Prod Elf-Aquitaine 21:153-186

21. King LC (1950) Outline and distribution of Gondwanaland. Geol Mag 87:99-110

22. Stoneley R (1966) The Niger delta region in the light of the theory of continental drift. Geol Mag 103:385-397

23. Grant NK (1971) The South Atlantic Benue Trough and Gulf of Guinea Cretaceous Triple junction. Geol Soc Am Bull 82:2259-2298

24. Olade MA (1975) Evolution of Nigeria's Benue Trough: a tectonic model. Geol Mag 112:575-583

25. Benkhelil J (1982) Benue trough and Benue chain. Geol Mag 119:158-168
26. Guiraud R, Maurin JC (1982) Early Cretaceous rifts of western and central Africa: an overview. Tectonophysics 213:153-168

27. Zaborski PM (1998) A review of the Cretaceous system in Nigeria. Africa Geoscience Review 5:385-483

28. Tukur A, Samaila NK, Grimes ST, Kariya II, Chaanda MS (2015) Two member subdivision of the Bima Sandstone, Upper Benue Trough, Nigeria: based on sedimentological data. J Afric Earth Sci 104:140-158

29. Rollinson HR (1993) Using geochemical data: evaluation, presentation, interpretation. Longman Group, London

30. Potter PE, Pettijohn FJ (1963) Palaeocurrents and basin analysis. Springer, Berlin

31. Lindholm R (1987) A practical approach to sedimentology. Allen \& Unwin, London

32. Pettijohn FJ, Potter PE, Siever R (1972) Sand and sandstones. Springer, New York, p 618

33. Fedo CM, Nesbitt HW, Young GM (1995) Unraveling the effects of potassium metasomatism in sedimentary rocks and paleosols, with implications for paleoweathering conditions and provenance. Geology 23:921-924

34. Condie KC, Lee D, Farmer L (2001) Tectonic setting and provenance of the Neoproterozoic Utah Mountain and Big Cootonwood groups, northern Utah: constraints from geochemistry, Nd isotopes, and detrital modes. Sediment Geol 141:443-464

35. Tawfik HA, Salah MK, Maejima W, Armstrong-Altrin JS, AbdelHameed AT, El Ghandour MM (2017) Petrography and geochemistry of the Lower Miocene Moghra sandstones, Qattara Depression, north Western Desert, Egypt. Geol J. https://doi. org/10.1002/gj.3025

36. Hernández-Hinojosa V, Montiel-García PC, Armstrong-Altrin JS, Nagarajan R, Kasper-Zubillaga JJ (2018) Textural and geochemical characteristics of beach sands along the Western Gulf of Mexico, Mexico. Carpathian J Earth Environ Sci 13:161-174

37. Roser BP, Cooper RA, Nathan SA, Tulloch AJ (1996) Reconnaissance sandstone geochemistry, provenance, and tectonic setting of the lower Paleozoic terrains of the West Coast and Nelson, New Zealand. NZ J Geol Geophys 39:1-16

38. Cox R, Lowe DR, Cullers RL (1995) The influence of sediment recycling and basement composition on evolution of mudrock chemistry in the southwestern United States. Geochim Cosmochim Acta 59:2919-2940

39. Nesbitt HW, Young GM (1982) Early Proterozoic climates and plate motions inferred from major element chemistry of lutites. Nature 299:715-717

40. Harnois $L$ (1988) The CIW index: a new chemical index of weathering. Sediment Geol 55:319-322

41. Hayashi K, Fujisawa H, Holland HD, Ohmoto H (1997) Geochemistry of 1.9 Ga sedimentary rocks from northeastern Labrador, Canada. Geochim Cosmochim Acta 61:4115-4137

42. Roser BP, Korsch RJ (1988) Provenance signatures of sandstonemudstone suites determined using discriminant function analysis of major-element data. Chem Geol 67:119-139

43. Verma SP, Armstrong-Altrin JS (2013) New multidimensional diagrams for tectonic discrimination of siliciclastic sediments and their application to Precambrian basins. Chem Geol 355:117-180

Publisher's Note Springer Nature remains neutral with regard to jurisdictional claims in published maps and institutional affiliations. 